\title{
Structural Models of Customer Loyalty on Star Hotel in Medan, Indonesia
}

\begin{tabular}{|c|c|}
\hline & $\begin{array}{r}\text { Dedek Kurniawan Gultom* } \\
\text { Universitas Muhammadiyah Sumatera Utara } \\
\text { Jalan Kapten Muchtar Basri No. } 3 \text { Medan, Indonesia } \\
\text { dedekkurniawan@umsu.ac.id }\end{array}$ \\
\hline \multirow[t]{2}{*}{$\begin{array}{l}\text { Submitted Date : } \\
1 \text { June } 2021 \\
\text { Accepted Date : } \\
22 \text { October } 2021\end{array}$} & $\begin{array}{r}\text { Nadia Ika Purnama } \\
\text { Universitas Muhammadiyah Sumatera Utara } \\
\text { Jalan Kapten Muchtar Basri No. } 3 \text { Medan, Indonesia } \\
\text { nadiaika@umsu.ac.id }\end{array}$ \\
\hline & $\begin{array}{r}\text { Muhammad Arif } \\
\text { Universitas Muhammadiyah Sumatera Utara } \\
\text { Jalan Kapten Muchtar Basri No. } 3 \text { Medan, Indonesia } \\
\text { muhammadarif@umsu.ac.id }\end{array}$ \\
\hline
\end{tabular}

\section{Suggested Citation:}

Azhar, M. E., Jufrizen, Prayogi, M. A., \& Sari, M. (2018). The Role of Marketing Mix and Service Quality on Tourist Satisfaction and Loyalty at Samosir. Revista de Turism-Studii Si Cercetari in Turism, 26.

Abstract:

This study aims to analyze directly and indirectly the service quality and hotel image on consumer satisfaction and customer loyalty. The location of this study is in several star hotels in Medan such as Graha Serela, Santika Premier Dyandra, Polonia, Grand Swiss-Bell, JW Marriot, Garuda Plaza, and Grand Aston City Hall Hotel. Populations in this study are guests who staying at a Starred Hotel in Medan in 2019, while the sample is determined as many as 215 consumers (hotel guests). Data answering techniques used are interviews, questionnaires and documentation studies. The data analysis method used in this study is Structural Equation Modelling (SEM). The results of research show directly, the quality of service provided to Consumer Satisfaction, Service Quality affect on Customer Loyalty, Hotel Image against Consumer Satisfaction, Hotel Image affect Customer Loyalty and Consumer Satisfaction against Customer Loyalty. Directly, the service quality and hotel image of customer loyalty through customer satisfaction.

Keywords: Customer Loyalty; Image, Satisfaction; Service Quality

JEL Classification: M30, M31

${ }^{*}$ Corresponding Author 


\section{Research Background}

Medan is the capital of the province of North Sumatra and is the third largest city in Indonesia after Jakarta and Surabaya. Medan is one of the metropolitan cities and is a gateway in the Western part of Indonesia. As the capital of the North Sumatra province, Medan is the center of almost all activities, both in the political, economic and socio-cultural fields. To anticipate the arrival of foreign visitors and local visitors to Medan with a variety of purposes and interests, the need for supporting facilities for non-permanent residence for several days or weeks, namely hotels.

Hotels in Medan, currently trying to offer a variety of accommodations aimed at customer satisfaction (guests), which is certainly tailored to the hotel classes, such as low or star class. According to statistics from the Department of Tourism and Culture of Medan in 2016, to date in Medan there are 51 starred hotels with main market, namely business visitors. The existence of hotels is usually supported by facilities such as seminar rooms (siding), meeting rooms, party rooms, and others. From the researcher's observations, there are several new phenomena that are currently appearing in the hotel business in the Medan, namely the increase in occupancy rates in four-star hotels such as Santika Priemere Dyandra, Graha Serela, and Polonia, on the contrary decreasing in five-star hotels such as Grand Aston City Hall, Grand Swiss-Bell and JW Marriot Hotel. This is expected to occur because four-star hotels in Medan have a larger market share than five-star hotels, given that Medan is a metropolitan city for business and transit cities are also a gateway for local migrants, investors, foreign business people such as from Singapore, Thailand, China and Malaysia.

In connection, to build the loyalty of visitors (customers) of the hotel, the hotel in Medan continues to improve the service process provided to be able to maintain good performance results. Loyal customers will use the product or service continuously from the same company. Loyalty is not only a strong foundation for the company but also reflects the company's potential for future growth (Widyawati, 2008). The customer is loyal or not seen from the consistency of their buying behavior towards a brand (Sutisna, 2001). Based on exposure to customer loyalty, meaning can be taken from the consistency of a customer to buy the same product in different time periods. Customer loyalty is inseparable from the satisfaction that has been felt by these customers. Better customer satisfaction at the hotel, the higher the customer loyalty to the hotel due to the satisfaction felt by the customer (Chen \& Japarianto, 2014).

Consumer satisfaction is very important for every organization, but studies show that satisfying consumers is not enough, because there is no guarantee that satisfied consumers will return to buy again (Dube, Renaghan, \& Miller, 1994). Consumer loyalty describes consumers who are not only satisfied but also happy with the product or service (Bhote, 1996). Such consumers not only buy back company goods or services, but extend their loyalty to the large number of goods and other services produced by the company. Having loyal customers allows a company to develop and maintain long-term customer relationships (Bitner \& Zeithaml, 1996).

In addition, because the cost of acquiring new customers is far greater than the cost of maintaining it, having loyal customers has the potential to increase company profits. Consumer satisfaction and image are two factors that have been identified as important antecedents of consumer loyalty (Selnes, 1993); (Ostrowsky, O'Brien, \& O'Brien, 1993). In relation to the relationship between image and customer satisfaction most of the previous studies measured the relationship between these two factors separately. Some researchers focus on the relationship between consumer loyalty and image (Ostrowsky et al., 1993); (Yoon, Guffey, \& Kijewski, 1993), while other researchers focused on the relationship between customer loyalty and customer satisfaction (Mazanec, 1995); (Woodside, Frey, \& Daly, 1997). However, the relationships between customer loyalty, customer satisfaction and image in the hospitality industry are not given much attention.

Service quality is the magnitude of the difference between consumers' expectations or desires and their level of perception (Laksana, 2008). Quality of service is a statement of attitude towards the comparison between expectations and performance (Kotler \& Keller, 2016). Service quality is something that consistently meets or exceeds consumer expectations (Lovelock \& Wright, 2007). Whereas (Yamit, 2013) states the quality of service can be seen from the comparison between consumer expectations with service performance. Service quality is a determining factor in the competitiveness of service companies. Therefore the quality of service is very important for a company. Quality of service can affect satisfaction from consumers and can determine customer loyalty (Irina \& Zaiţ, 2016). Quality service from the company will increase customer satisfaction which leads to customer loyalty, as conducting promotions to others (Ledden, Kalafatis, \& Mathioudakis, 2011). Consumer satisfaction is the result of consumer evaluations after making a purchase, and consumers feel that the goods or services purchased have the same performance or exceed their expectations (Kotler \& Keller, 2016). Other empirical research has also proven that service quality influences customer satisfaction (Rahma, 2015); (Mutmainnah, 2017); (Saleem \& Raja, 2014); (Venkateswarlu, Ranga, \& Sreedhar, 2015); (Lunarindiah, 2016); (Mohamad, 
Yazid, Khatib, \& Azam, 2017); (Banjarnahor, 2017); (Alber, 2017); (Purbandari, Sugandini, \& Sutiono, 2018); (Azhar, Jufrizen, Prayogi, \& Sari, 2018); (Zakiy, 2019); (Chien \& Chi, 2019) and (E. Susanti, 2018). Loyal consumers are consumers who at any time will buy back at the same service provider and return to praise or be positive towards these service providers (Markovic, Jankovic, \& Segaric, 2010). The results of their study found that customers experience in consuming bank services will produce satisfaction or dissatisfaction and will ultimately result in customer loyalty (Giovanis et al., 2015). Likewise, research ((Saleem \& Raja, 2014); (Rahma, 2015); (Lunarindiah, 2016); (Mutmainnah, 2017); (Mohamad et al., 2017); (Majid, Samsudin, Noorkhizan, Zaki, \& Bakar , 2018); (Azhar et al., 2018) and (CE Susanti, 2019) which concluded that quality affects loyalty.

Image is seen as an important variable that influences marketing activities. Image is very important for any organization because of the ability of the image to influence consumer perceptions about the goods and services offered (Bitner \& Zeithaml, 1996). As a result, the image influences consumer buying behavior with respect to an organization's products and services. This section discusses concepts and research that support the significance of imagery. Image is the impression someone feels about an object or item or the organization as a whole which will then be stored in consumers' memories (Kotler \& Keller, 2016). To form a good image, companies must build a good name and reputation and also strengthen their competence (Jasfar \& Kristaung, 2012). Therefore, building and maintaining that image is important for a service organization if it wants to gain and maintain customer loyalty (Hoq, Amin, \& Rumki, 2010). It is very important for companies to have a good image because the image will to function as a filter of all activities that occur within the company (Ganguli \& Roy, 2011). For example, when the service delivered by the company is not in accordance with the services expected by a consumer, a positive image that has been owned will protect the company if the consumer tells of his dissatisfaction or submit a negative Word of Mouth to his friends or relatives (Ganguli \& Roy, 2011). Further research (Christina, 2014), (Lunarindiah, 2016); (Mutmainnah, 2017); (Purbandari et al., 2018) and (Chien \& Chi, 2019) found that corporate image influences satisfaction. It is important to maintain a strong corporate image in to attract and retain consumers and keep them loyal to the company (Jasfar \& Kristaung, 2012). The image does not have an influence on value and satisfaction, but it does affect loyalty (Pinzón \& Saura, 2011). Whereas (Hsu \& Cai, 2009) in his research found that image does not affect satisfaction but image influences loyalty. Whereas (Christina, 2014); (Mutmainnah, 2017); (Majid et al., 2018); (Radiman, Gunawan, Wahyuni, \& Jufrizen, 2018) in their research found that image influences loyalty.

Customer satisfaction means a comparison between what consumers expect and what consumers feel when using the product. If consumers feel the performance of the product is the same or exceeds their expectations, it means they are satisfied. Conversely, if the product performance is less than expectations, it means they are not satisfied. Satisfaction is pleasurable fulfilment that is satisfying customer expectations (Oliver, 2010). Customer satisfaction is an emotional reaction to post-purchase customers which can be anger, dissatisfaction, irritation, neutrality, excitement or pleasure (Lovelock \& Wright, 2007). Customer satisfaction is the level of customer feeling after comparing the perceived service performance to expectations (Kotler \& Keller, 2016). Customer satisfaction is an evaluation of after-purchase or evaluation results after comparing what is felt with his expectations (Yamit, 2013). Satisfaction is the level of feeling after comparing the perceived performance or results with expectations (Sumarwan, 2012). Assessing customer satisfaction, advocates the use of a multiitem scale that is not only evaluating customer satisfaction in terms of company service, but also components in the service process (Oliver, 2010). In measuring satisfaction, indicators used are service responsiveness, professionalism and overall satisfaction with services (Supranto, 2011). Customer loyalty is a behavior related to services or companies. Consumers become loyal because they consumers feel satisfied and wish to continue their relationship with the company (Ganguli \& Roy, 2011). While research (Batista, Couto, Botelho, \& Faias, 2014); (Christina, 2014); (Saleem \& Raja, 2014); (Rahma, 2015); (Ganguli \& Roy, 2011), (Alber, 2017); (Mutmainnah, 2017); (Mohamad et al., 2017); (Azhar et al., 2018); and (Susanti, 2018) found that satisfaction affects loyalty.

Customer loyalty is the customer's commitment to a brand, store, or supplier, based on a positive attitude and is reflected in consistent repurchases (Tjiptono, 2012). Customer loyalty is the commitment of customers to stay in depth to re-subscribe or re-purchase selected products/ services consistently in the future, even though the influence of the situation and marketing efforts have the potential to cause behavior change (Hurriyati, 2005). Customer loyalty occurs in several phases. The phase starts from 1) Cognitive loyalty or loyalty that is based only on brand confidence. 2) Affective loyalty or liking or attitude towards a brand is based on the opportunity to use 
satisfaction cumulatively. 3) Conative loyalty which shows a condition of loyalty that contains whether the first appearance shows a deep commitment to buy. 4) Action loyalty, where the intention is converted to action (Oliver, 2010). The factors that influence consumer loyalty are as follows: 1) product/ service performance, 2) company/ product/ brand image, 3) price and value relationship, 4) employee performance/ achievement, 5) competition, 6) product delivery system timely, and 7) relationship of satisfaction with consumers (Cravens \& Piercy, 2013). Loyal customers are important assets for the company, this can be seen from the characteristics they have, as revealed by (Griffin, 2010) there are four characteristics of loyal customers, namely: 1) Making regular repeat purchases, 2 ) Buying outside the product/ service line (Purchases across product and service lines), 3) Recommending other products (Refers other), and 4) Demonstrating immunity from the attractiveness of similar products from competitors.

\section{Research Methods}

This study uses an explanatory research approach, which aims to explain the causal relationship between the research variables and the testing hypothesis (Nasution, et al., 2020). The location of this research is in several star hotels in Medan such as Graha Serela, Santika Priemere Dyandra, Polonia, Grand Swiss-BelL, JW Marriot, Garuda Plaza, and Grand Aston City Hall Hotel. The population in this study were guests staying at Starred Hotels in Medan in 2019. The sampling technique was using non-probability sampling techniques. While the sample size in this study refers to the opinion (Ghozali, 2008) which states that the number of samples can be calculated from the size of the indicator multiplied by 5 to 10 . This study uses four construct variables with a total indicator number of 43 , so the sample needed is a minimum of $43 \times 5=215$ people. In this study, the authors conducted data processing in the form of a questionnaire that consisting of 16 statement items for service quality variables, nine statements for hotel image variables, 10 statement items for customer satisfaction variables and 8 statement items for consumer loyalty variables. The research questionnaire was distributed as many as 250 sets to the target respondents, namely customers of star hotels in the city of Medan. Based on the Likert scale research provisions in the above table, it is understood that the above provisions apply both in calculating the variables of Service Quality, Hotel Image, Consumer Satisfaction and Customer Loyalty. Then for each respondent who answers the research questionnaire, the highest score is given a value of 5 , and the lowest score is given a weighting of 1 . The type of data collected to support the variables studied are primary data. Data collection techniques used were interviews, questionnaire, and study documentation. The research subjects as a source of quantitative data in this study were hotel customers who were targeted by the study. Customers who are the subjects of this study are customers who stay overnight. The analytical method used in this study is the analysis of the Structural Equation Model with data processing using the Lisrel 8.0 computer program.

\section{Result}

The results of the research, data management and discussion are described in this chapter. While stated in the previous chapter, this research was conducted using a survey method with Structural Equation Modeling (SEM) techniques. To find out the percentage level based on the age of 215 respondents can be seen in the following table:

Table 1. Respondents Distribution by Age

\begin{tabular}{clccr} 
No & & Age & Amount (People) & Percentage (\%) \\
\hline 1 & $<25$ Years & & 14 & 10.4 \\
2 & $26-35$ Years & 54 & 40.3 \\
3 & $36-45$ Years & 41 & 30.6 \\
4 & $>45$ Years & & 25 & 18.66 \\
& & Total & 215 & 100 \\
\hline
\end{tabular}

Source: Data Processed (2021)

From table 1, it is known that the majority of the respondents age is at the age of 26-35 years which is equal to $40.30 \%$, the age between $36-45$ years at $30.60 \%$, then above 45 years at $18.66 \%$, while the age of the respondents the least is $<25$ years which is $10.45 \%$. To find out the percentage level based on gender from 215 respondents, it can be seen in the following table: 
Table 2. Respondents Distribution by Gender

\begin{tabular}{|c|c|c|c|c|}
\hline No. & Gender & & Amount (People) & Persentage $(\%)$ \\
\hline 1 & Man & & 129 & 60 \\
\hline 2 & Woman & & 86 & 40 \\
\hline
\end{tabular}

Source: Data Processed (2021)

Based on the data in the table above, the respondents gender showed that of 215 respondents, the more dominant male sex was 129 people by $60 \%$, while the smallest were 86 female respondents or $40 \%$. To find out the percentage level based on the level of education of 215 respondents, it can be seen in the following table:

Table 3. Respondents Distribution by Educational Levels

\begin{tabular}{|c|c|c|c|c|}
\hline No. & Educational & & Amount (People) & Persentage (\%) \\
\hline 1 & Senior High School & & 34 & 15.81 \\
\hline 2 & Diploma & & 34 & 15.81 \\
\hline 3 & Bachelor & & 80 & 37.21 \\
\hline 4 & Master & & 67 & 31.16 \\
\hline & & Total & 215 & 100 \\
\hline
\end{tabular}

Source: Data Processed, 2021

Based on the data in the table above showed that the education level of the respondents used as samples in this study is known, that respondents who have bachelor background are 80 people or $37.21 \%$, master respondents are 67 people or $31.16 \%$, respondents with Diploma 3 as many as 34 people or $15.81 \%$ and those with senior high school as many as 34 people or $15.81 \%$. To find out the percentage level based on the work of 215 respondents, it can be seen in the following table:

Table 4. Respondents Distribution by Profession

\begin{tabular}{|c|c|c|c|}
\hline No. & Profession & Amount (People) & Persentage (\%) \\
\hline 1 & Entrepreneurs & 65 & 30.23 \\
\hline 2 & Civil Servants & 32 & 14.88 \\
\hline 3 & Employees & 63 & 29.3 \\
\hline 4 & Experts & 35 & 16.28 \\
\hline 5 & Housewives & 12 & 5.58 \\
\hline \multirow[t]{2}{*}{6} & Others & 8 & 3.72 \\
\hline & & 215 & 100 \\
\hline
\end{tabular}

Source: Data Processed (2021)

Based on the table above described that the majority of respondents have the status of being entrepreneurs, amounting to $30.23 \%$. In the second place with a percentage of $29.30 \%$ of respondents working as private employees, respondents with professional work as much as $16.28 \%$. Respondents with State jobs were $14.88 \%$, respondents with housewives were $5.58 \%$, and others $3.72 \%$

Table 5. Descriptive Statistics

\begin{tabular}{cccccc} 
& N & Minimum & Maximum & Mean & Std. Deviation \\
\hline Service Quality & 215 & 44 & 80 & 62.502 & 6.996 \\
Hotel Image & 215 & 15 & 45 & 37.069 & 4.386 \\
Satisfaction & 215 & 27 & 50 & 41.669 & 4.291 \\
Loyalty & 215 & 28 & 40 & 35.911 & 2.996 \\
Valid N (listwise) & 215 & & & & \\
\hline
\end{tabular}

Source: Data Processed (2021)

According to the data processing results above, it shows that the number of respondents $(\mathrm{N})$ is 215 , out of 215 respondents for the Service Quality variable, the average score is 62.502. Respondents answer scores about Service Quality ranged from 44 to 80 with a standard deviation of 6.996. Variable Hotel Image obtained an average count answer score of 37.069. Respondents' scores on Image Hotels ranged from 15 to 45 with a 
standard deviation of 4.386. Consumer Satisfaction variable obtained an average count answer score of 41.669. Respondents answer scores on Consumer Satisfaction ranged from 27 to 50 with a standard deviation of 4.291. Customer Loyalty Variations obtained an average count answer score of 35.911. Respondents answer scores regarding Customer Loyalty ranged from 28 to 40 with a standard deviation of 2.996 .

\section{Analysis of Causal Relations}

Statistical testing for the causal relationship of this structural model was carried out with a significance level of $5 \%$ so that the critical value of the t-value was \pm 1.96 . The estimated results of all the causal relationships in the study can be seen in the following LISREL 8.80 Output:

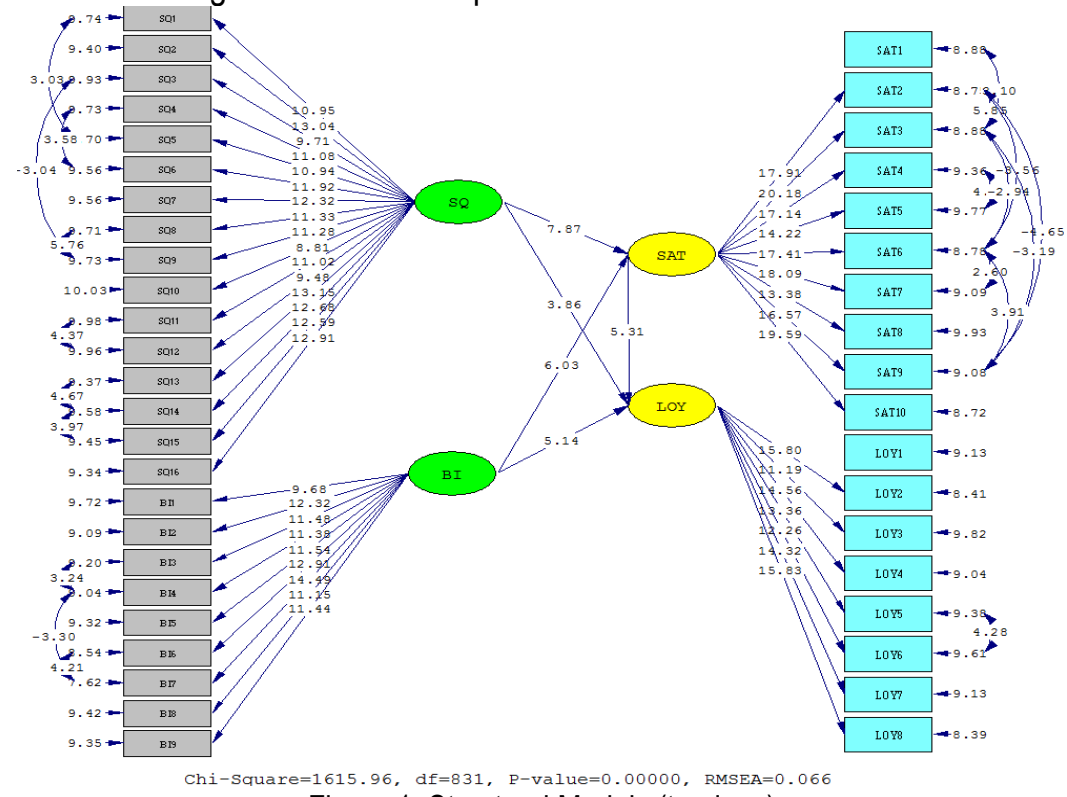

Figure 1. Structural Models (t-values)

Source: Data Processed (2021)

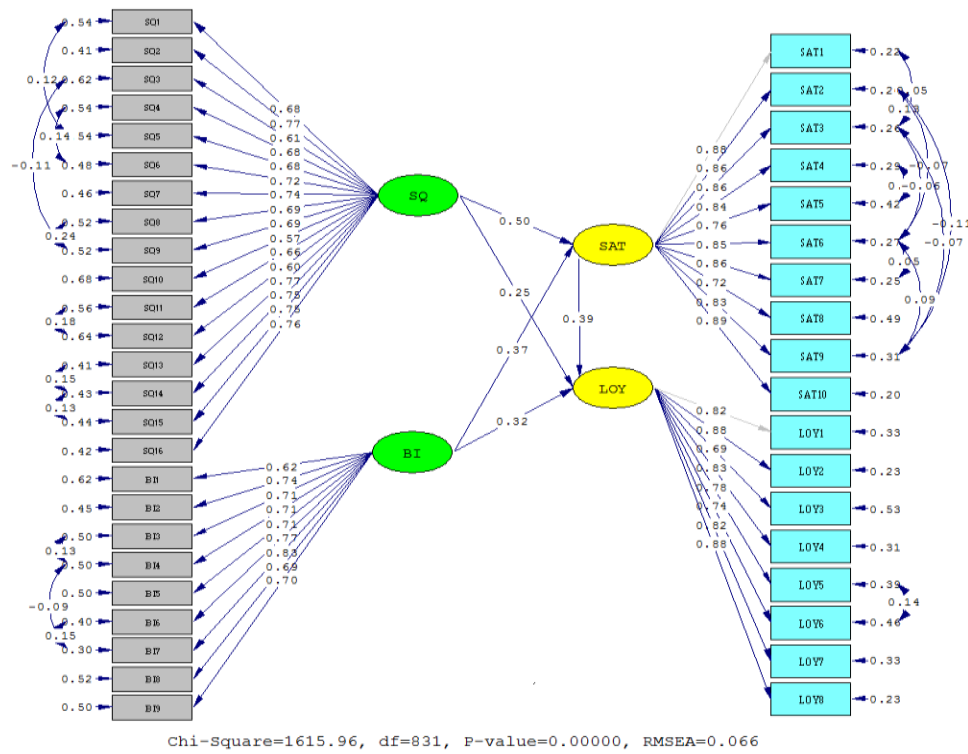

Figure 2. Structural Models (standardized Solution)

Source: Data Processed (2021)

\section{Hypothesis Test}

Hypothesis testing analysis was performed with a significance level of $5 \%$, resulting in a critical t-value of \pm 1.96 . The hypothesis is accepted if the t-value obtained 1.96, while the hypothesis is not supported if the t-value obtained $<1.96$. The following is a table of hypothesis testing to answer the entire research question: 
Table 6. Direct Hypothesis Testing

\begin{tabular}{clccc} 
Hypothesis & Statements & T-Count & T-Table & Information \\
\hline $\mathrm{H}_{1}$ & Service Quality Affects Consumer Satisfaction & 7.87 & & Significant \\
$\mathrm{H}_{2}$ & Service Quality Affects Customer Loyalty & 3.86 & & Significant \\
$\mathrm{H}_{3}$ & Hotel Image Affects Consumer Satisfaction & 6.03 & \multirow{2}{*}{ S.96 } & Significant \\
$\mathrm{H}_{4}$ & Hotel Image Affects Customer Loyalty & 5.14 & & Significant \\
$\mathrm{H}_{5}$ & Consumer Satisfaction Affects Customer Loyalty & 5.31 & & Significant \\
\hline
\end{tabular}

Source: Data Processed (2021)

In this study, there are two hypotheses for indirect effects. Hypothesis testing analysis was performed with a significance level of $5 \%$, resulting in a critical $t$-value of \pm 1.96 . Therefore, the hypothesis is accepted if the $t-$ value obtained 1.96, while the hypothesis is not supported if the t-value obtained $<1.96$. The following is a table of hypothesis testing to answer the indirect effect.

Table 7. Indirect Hypothesis Testing

\begin{tabular}{|c|c|}
\hline Hypothesis & Intervening \\
\hline Effect of Indirect Variables (tcount) & Consumer Satisfaction \\
\hline Service Quality Affects Customer Loyalty & 4.51 \\
\hline Hotel Image Affects Customer Loyalty & 4.14 \\
\hline
\end{tabular}

Source: Data Processed (2021)

Based on the table, which contains the conclusions of the results of the research model hypothesis, it can be concluded that there are 2 (two) significant direct influences based on the tcount greater than table $a=5 \%$ (1.96). Service Quality affects Customer Loyalty through the Consumer Satisfaction variable, which refers to the table and the output of the t-value of 4.51 which is greater than 1.96, and the weight of the effect of 0.20 which means that Consumer Satisfaction can positively mediate the effect of Service Quality on Customer Loyalty with a weight of 0.20 .

Hotel Image has an effect on Customer Loyalty through the Consumer Satisfaction variable, which refers to the table and the output of the t-value of 4.14 , is greater than 1.96, and the weight of the effect of 0.15 , means that Consumer Satisfaction can positively mediate the effect of Hotel Image on Customer Loyalty with a weight of 0.15 .

\section{Discussion}

\section{The Effect of Service Quality on Consumer Satisfaction}

Based on the results of data processing, the results showed that Service Quality has a significant effect on hotel guest satisfaction. Satisfaction felt by hotel guests is the result of the respondents' (guests) rating based on the experience of the services provided by Starred Hotels in Medan. It can be concluded that if better Quality of Service provided or carried out, the satisfaction of hotel guests as being served will be better. This research is in line with research conducted by (Tefera \& Govender, 2015), service quality was found to have a significant impact on customer satisfaction and perceived value. The research and theory developed by (Bucak, 2014), evaluating customer perceptions and their relationship to satisfaction regarding service quality are widely recognized as effective strategies for increasing profitability in the hospitality and hotel industry that has a high level of customer contact. These results are in line with studies conducted by (Mohajerani \& Miremadi, 2012); (Ranjbarian, Sanayei, Kaboli, \& Hadadian, 2012); (H. D. Kim \& Lough, 2007); (Cheng \& Rashid, 2013); (Batista et al., 2014); (Karyose, Astuti, \& Ferdiansjah, 2017); (Liat, Mansori, Chuan, \& Imrie, 2017); (lqbal, Hassan, \& Sharif, 2017); (Nurcahyo, Fitriyani, \& Hudda, 2017); (Radiman et al., 2018); (Chien \& Chi, 2019); (Azhar et al., 2018); (Djamereng, Basalamah, Mursalim, \& Dani, 2019) and (Alauddin, Ahsan, Mowla, Islam, \& Hossain, 2019).

\section{The Effects of Service Quality on Customer Loyalty}

Based on the results of data processing, it is known that the Service Quality variable has a significant positive effect on Customer Loyalty. Research and theory developed by (Al-Rousan, Ramzi, \& Mohamed, 2010) services that are perceived by guests as appropriate or close to the expectations of guests, guests will feel comfortable so 
that there is an interest or desire to use the service again. It also can be concluded that if the better Service Quality is performed or provided it will stimulate the loyalty that arises from guests will also increase, and this is also appropriate as the purpose of research that understands the significant effect of Service Quality on hotel guest loyalty. The results of this study are also in line with research conducted by (Hu, 2011); (Akbar, Som, Wadood, \& Alzaidiyeen, 2010), (Karyose et al., 2017); (Nurcahyo et al., 2017); (Iqbal et al., 2017); (Radiman et al., 2018); (Azhar et al., 2018); (Djamereng et al., 2019) and (Alauddin et al., 2019).

\section{The Effects of Hotel Image on Consumer Satisfaction}

Based on the data processing, it is known that the Hotel Image variable has a significant positive effect on the Hotel Image. This means that better the Image Hotel will be able to increase the customer satisfaction of Starred Hotels in Medan and vice versa. Hotels must continue to improve services to meet customer standards and needs, hotel management also continues to strive to promote this hotel in order to raise the Image Hotel which is well known for hotels with a good image and this is already known by customers who have stayed at the hotel so that customers feel that Starred Hotels in the city of Medan is the best hotel. Research (Kandampully \& Hu, 2007) states that the most effective way to keep Hotel Image good is that hotels must be able to satisfy customers by maintaining their reputation and service, remaining consistent in providing services to customers, creating quality human resources, creating product advertisements services to create a strong and impressive hotel brand image in the eyes of customers. Therefore, the consistency of service performed by the hotel from time to time must be able to create a better image and reputation compared to competing hotels so that customers are satisfied when staying at this hotel, whenever the customer stays the service provided remains the same so that customers feel that the choice to stay at this hotel is the right choice. The findings in this study also support the results of previous studies conducted by (Clemes, $\mathrm{Wu}, \mathrm{Hu}, \&$ Gan, 2009) showing that image has a positive influence on customer satisfaction. The results of this study also support other studies from (Alireza, Ali, \& Aram, 2011); (Ranjbarian et al., 2012); (lqbal et al., 2017); (Karyose et al., 2017) and (Djamereng et al., 2019).

\section{The Effects of Hotel Image on Customer Loyalty}

Based on the results, it is known that the Hotel Image variable has a significant positive effect on Customer Loyalty. It's means that the better the Image Hotel will be able to increase the customer loyalty of Starred Hotels in Medan and vice versa. The result of this study are in line with research conducted by (Alireza et al., 2011); (Brown \& Mazzarol, 2009) and (Kandampully \& Suhartanto, 2000). Conformity between what customers perceive of hotel services and those offered so as to shape customer behavior, this shows that customers feel that the image of this hotel is better than competing hotels which will form the intention to behave customers to be loyal by making this hotel the first choice for staying, then we can see that the image that has been formed in the minds of customers concerns aspects of the name, reputation, service price and quality of service received it forms the customer to tell positive things and are willing to recommend to others. A good hotel image will strengthen the position of the hotel in competition and win the trust of the public. Creating an attractive hotel atmosphere and maintaining a good hotel appearance is a way to create a Hotel Image in the eyes of customers. This affects the hotel where if the Image Hotel is good, consumers will more easily decide to choose a place to stay, even customers will tell positive things about this hotel and recommend this hotel to others who want to stay. The result of this study are in line with research (Kandampully \& Hu, 2007) which states that the key to earning customer loyalty is to improve the good image of the hotel. The results of this study support research conducted by (Clemes et al., 2009) and (Chen \& Tsai, 2007) who find that images have a direct influence on behavioral intentions. Subsequent research focusing on the hotel service industry also found that Hotel Image influences behavioral intentions (H.-B. Kim \& Kim, 2005). These results also support research from (Liat et al., 2017); (Iqbal et al., 2017); (Karyose et al., 2017) and (Djamereng et al., 2019), who found that the image had a positive and significant effect on intention to behave.

\section{The Effects of Consumer Satisfaction on Customer Loyalty}

Based on the results of data processing from the structural model, it was concluded that the Consumer Satisfaction variable had a significant positive effect on Customer Loyalty. This gives the meaning that the customer feels satisfied from the experience they have felt and raises customer satisfaction with the presentation of the hotel. Satisfaction felt by hotel guests is the result of the guests' personal experience in using the services of the service provider, if the service provider is deemed in accordance with the personal values of the guest and makes their satisfied, it is not impossible that the guest will use the service again and even recommend it to other parties. Fornell (Lupiyoadi \& Hamdani, 2006) asserted that many benefits were received by the company with the 
achievement of high customer satisfaction, one of which is customer loyalty. This is in line with research conducted by (Kandampully \& Hu, 2007); (Torres-Moraga, Vásquez-Parraga, \& Zamora-González, 2008); (Mohajerani \& Miremadi, 2012); (Cheng \& Rashid, 2013); (Batista et al., 2014); (Liat et al., 2017); (lqbal et al., 2017); (Karyose et al., 2017); (Nurcahyo et al., 2017) and (Alauddin et al., 2019).

\section{The Effects of Service Quality on Customer Loyalty through Customer Loyalty}

Service Quality affects Customer Loyalty through the Consumer Satisfaction variable, meaning that Consumer Satisfaction can positively mediate the effect of Service Quality on Customer Loyalty. In the study conducted, it was established, in general there was a positive correlation between customer satisfaction and customer loyalty. Customer satisfaction is widely recognized as an indicator of customer loyalty in the hotel industry. This study also shows that satisfied hotel guests tend to remain loyal to the service provider concerned therefore customer loyalty is a highly valued asset and is a reflection of the long-term success of a hotel if it can expand and maintain customer loyalty. The conclusion is that the quality of service and in accordance with the needs of guests can have an impact on the level of guest satisfaction. The level of guest satisfaction with the Service Quality provided is a comprehensive assessment of the advantages of a service related to facilities, services, and good employee responses, it can give an impression or experience that is good for guests, so they can bring trust and loyalty to the hotel. These results are in line with studies conducted by (Caruana, 2002); (Ismail, Haron, Ibrahim, \& Isa, 2006); (Kheng, Mohamad, Ramayah, \& Mosahab, 2010) and (Djamereng et al., 2019).

\section{The Effects of Hotel Image on Customer Loyalty through Consumer Satisfaction}

Hotel Image affects Customer Loyalty through the Consumer Satisfaction variable, meaning Consumer Satisfaction can positively mediate the effect of Hotel Image on Customer Loyalty. Hotel Image also has a significant and positive influence on customer loyalty, and also product image and customer satisfaction have a significant and positive effect on customer loyalty. It can be said that the product image directly affects customer loyalty and indirectly influences customer loyalty through customer satisfaction as a mediating variable. The product image variable is known to have a direct influence on the customer loyalty variable after previously controlling the customer satisfaction variable, so customer satisfaction in this study cannot be said to be perfect or complete mediation. The influence of product image variables on customer loyalty after controlling customer satisfaction variables was slightly reduced but still significant, so customer satisfaction in this study was stated as partial mediation or partially mediated the relationship between product image and customer loyalty. According to the development of partial mediation conducted by (Zhao, Lynch, \& Chen, 2010) and (Djamereng et al., 2019), customer satisfaction in this study can be said to be complementary mediation.

However, the findings from the results of this study also found that a good Image Hotel indirectly influences customer behavior intentions through customer satisfaction, but customer satisfaction is not a good intermediate variable in other words that with Hotel Image embedded in the mind of the customer is good it will make the customer will become a loyal customer to the hotel without the need for that customer to feel satisfaction while staying at the hotel.

\section{Conclusion}

Based on the results of research on Starred Hotels in Medan City Medan showed that Service Quality has a significant positive effect on Consumer Satisfaction. Higher the Service Quality perceived by Respondents, better Consumer Satisfaction will be. Service Quality has a significant positive effect on Customer Loyalty. Higher the Service Quality perceived by Respondents, better Customer Loyalty will be. Hotel Image has a significant positive effect on Consumer Satisfaction. Higher the Hotel Image perceived by the Respondents, better the Consumer Satisfaction. Hotel Image has a significant positive effect on Customer Loyalty. Higher the Hotel Image perceived by the Respondents, better the Customer Loyalty will be. Consumer Satisfaction has a significant positive effect on Customer Loyalty, higher the Consumer Satisfaction perceived by Respondents, better Customer Loyalty will be. Service Quality affects Customer Loyalty through the Consumer Satisfaction variable, meaning that Consumer Satisfaction can positively mediate the effect of Service Quality on Customer Loyalty. Hotel Image affects Customer Loyalty through the Consumer Satisfaction variable meaning Consumer Satisfaction can positively mediate the effect of Hotel Image on Customer Loyalty. This study has several limitations, among others: only focus on examining star-rated hotels in Medan, whereas in other big cities there are also star-rated 
hotels. The next limitation is the number of respondents are 215 people. Both of these limitations cause the results of research cannot be generalized to all star-rated hotels in Indonesia. In addition, this research model only uses the loyalty variable as a consequence of Service Quality and Hotels Image. It is possible that there are other variables that are also a consequence of Service Quality and Hotel Image. Future studies should use more respondents as well as by adding a number of other five-star hotels in several major cities in Indonesia, so that the results can be generalized.

\section{References}

Akbar, S., Som, A. P. M., Wadood, F., \& Alzaidiyeen, N. J. (2010). Revitalization Of Service Quality To Gain Customer Satisfaction And Loyalty. International Journal of Business and Management, 5(6), 113-122.

Al-Rousan, Ramzi, M., \& Mohamed, B. (2010). Customer Loyalty and the Impacts of Service Quality: The Case of Five Star Hotels in Jordan International. International Journal of Economics and Management Engineering, 4(7), 1702-1708. https://doi.org/(DOI): doi.org/10.5281/zenodo.1331937

Alauddin, M., Ahsan, S. M. H., Mowla, M. M., Islam, M. M., \& Hossain, M. M. (2019). Investigating the Relationship between Service Quality, Customer Satisfaction and Customer Loyalty in Hotel Industry: Bangladesh Perspective. Global Journal of Management and Business Research: A Administration and Management, 19(1), 29-35.

Alber, R. F. (2017). Anteseden Customer Loyalty. Jurnal Manajemen Dan Pemasaran Jasa, 10(2), 293-310. https://doi.org/Doi: http://dx.doi.org/10.25105/jmpj.v10i1.2542

Alireza, F., Ali, K., \& Aram, F. (2011). How Quality, Value, Image And Satisfaction Create Loyalty At An Iran Telecom. International Journal of Business and Management, 6(8), 271-279. https://doi.org/DOI:10.5539/ijbm.v6n8p271

Azhar, M. E., Jufrizen, Prayogi, M. A., \& Sari, M. (2018). The Role Of Marketing Mix And Service Quality On Tourist Satisfaction And Loyalty At Samosir. Revista de Turism-Studii Si Cercetari in Turism, 26.

Azhar, M. E., \& Jufrizen, J. (2017). The Analysis of The Tourist Loyalty Determinant In the Area of Toba Lake. International Journal of Recent Scientific Research, 8(10), 20826-20832.

Azhar, M. E., Jufrizen, J., Prayogi, M. A., \& Sari, M. (2019). Effect of Marketing Mix and Service Quality on Tourist Satisfaction. In Proceeding of The 3rd International Conference on Accounting, Business \& Economics (UII-ICABE 2019) (pp. 133-140).

Banjarnahor, J. (2017). Anteseden Customer Satisfaction dan Dampaknya Pada Purchase Intention. Jurnal Manajemen Dan Pemasaran Jasa, 10(1), 141-156. https://doi.org/Doi: http://dx.doi.org/10.25105/jmpj.v10i1.1680

Batista, M. da G., Couto, J. P., Botelho, D., \& Faias, C. (2014). Tourist satisfaction and loyalty in the hotel business: An application to the island of São Miguel, Azores. Tourism \& Management Studies, 10(1), 1623.

Bhote, K. R. (1996). Beyond Customer Satisfaction to Customer Loyalty. New York: AMACOM.

Bitner, M. J., \& Zeithaml, V. A. (1996). Services Marketing. Boston: MCGraw-Hill.

Brown, R. M., \& Mazzarol, T. W. (2009). The Importance of Institutional Image To Student Satisfaction And Loyalty Within Higher Education. Higher Education, 58(1), 81-95.

Bucak, T. (2014). The Effect of Service Quality on Customer Satisfaction: A Research on Hotel Businesses. International Journal of Education and Research, 2(1), 1-12.

Caruana, A. (2002). Service loyalty: The Effects of Service Quality And The Mediating Role of Customer Satisfaction. European Journal of Marketing, 36(7/8), 811-828. https://doi.org/https://doi.org/10.1108/03090560210430818

Chen, C.-F., \& Tsai, D. C. (2007). How Destination Image and Evaluative Factors Affect Behavioral Intentions. Tourism Management, 28(4), 1115-1122. https://doi.org/https://doi.org/10.1016/j.tourman.2006.07.007

Chen, Y. S., \& Japarianto, E. (2014). Pengaruh Kepuasan, Hambatan Berpindah Dan Penyediaan Fasilitas Terhadap Customer Loyalty Di Hotel Novotel Surabaya. Jurnal Strategi Pemasaran, 2(1), 1-7.

Cheng, B.-L., \& Rashid, M. Z. A. (2013). Service Quality and the Mediating Effect of Corporate Image on the Relationship between Customer Satisfaction and Customer Loyalty in the Malaysian Hotel Industry. Gadjah Mada International Journal of Business, 15(2), 99-112.

Chien, L., \& Chi, S. (2019). Corporate image as a mediator between service quality and customer satisfaction: difference across categorized exhibitors. Heliyon, 5. https://doi.org/doi: 10.1016/j.heliyon.2019. e01307

Christina, F. S. (2014). Pengaruh Service Quality dan Citra Korporasi Terhadap Kesetiaan Pelanggan Melalui Kepuasan Pelanggan. Jurnal Manajemen Dan Pemasaran Jasa, 7(2), 91-124. 
Clemes, M. D., Wu, J. H.-C., Hu, B.-D., \& Gan, C. (2009). An Empirical Study Of Behaviour Intentions In Taiwan Hotel Industry. Innovative Marketing, 5(3), 30-50.

Cravens, D. W., \& Piercy, N. . (2013). Strategic Marketing. New York: McGraw-Hill International Edition.

Djamereng, A., Basalamah, S., Mursalim, \& Dani, I. (2019). No Title. International Journal of Economics, Business and Management Research, 3(03), 207-220.

Dube, L., Renaghan, L. M., \& Miller, J. M. (1994). Measuring customer satisfaction for strategic management. Cornell Hotel and Restaurant Administration Quarterly, 35(1), 39-47. https://doi.org/https://doi.org/10.1016/0010-8804(94)90063-9

Ganguli, S., \& Roy, S. K. (2011). Generic technology-based service quality dimensions in banking. International Journal of Bank Marketing, 29(2), 168-189. https://doi.org/https://doi.org/10.1108/02652321111107648

Ghozali, I. (2008). Aplikasi Analisis Multivariate dengan Program SPSS. Semarang: BP- Universitas Diponegoro.

Giovanis, A., Athanasopoulou, P., \& Tsoukatos, E. (2015). The role of service fairness in the service quality relationship quality - customer loyalty chain. Journal of Service Theory and Practice, 25(6), 744-776. https://doi.org/https://doi.org/10.1108/JSTP-11-2013-0263

Griffin, J. (2010). Customer Loyalty How To Earn it, How Keep It I. Kentucky: McGraw - Hill.

Hoq, M. Z., Amin, M., \& Rumki, N. S. (2010). The Effect of Trust, Customer Satisfaction and Image on Customers' Loyalty in Islamic Banking Sector. South Asian Journal of Management, 17(1), 70-93.

Hsu, C. H. C., \& Cai, L. (2009). Brand Knowledge, Trust and Loyalty - A Conceptual Model of Destination Branding. In International CHRIE Conference-Refereed Track (pp. 1-8).

Hu, Y.-J. (2011). How Brand Equity, Marketing Mix Strategy, And Service Quality Affect Customer Loyalty: The Case Of Retail Chain Stores In Taiwan. The International Journal of Organization Innovation, 4(1), 59-73.

Hurriyati, R. (2005). Bauran Pemasaran dan Customer Loyalty. Bandung: Alfabeta.

Iqbal, M. S., Hassan, M. U., \& Sharif, S. (2017). Interrelationship among Corporate Image, Service Quality, Customer Satisfaction, and Customer Loyalty: Testing the moderating impact of Complaint Handling. International Journal of Academic Research in Business and Social Sciences, 7(11), 667-688. https://doi.org/DOI: 10.6007/IJARBSS/v7-i11/3506

Irina, I., \& Zaiţ, A. (2016). Corporate reputation, satisfaction and loyalty - analysis of possible causal relationships. Romanian Journal of Marketing, (2), 47-56.

Ismail, I., Haron, H., Ibrahim, D. N., \& Isa, S. M. (2006). Service Quality, Client Satisfaction and Loyalty Towards Audit Firms: Perceptions Of Malaysian Public Listed Companies. Managerial Auditing Journal, 21(7), 738756. https://doi.org/https://doi.org/10.1108/02686900610680521

Jasfar, F., \& Kristaung, R. (2012). Sinergi Pemasaran Jasa Ritel. Jakarta: Universitas Trisakti Jakarta.

Kandampully, J., \& Hu, H. (2007). Do Hoteliers Need To Manage Image To Retain Loyal Customers? International Journal of Contemporary Hospitality Management, 19(6), 435-443. https://doi.org/https://doi.org/10.1108/09596110710775101

Kandampully, J., \& Suhartanto, D. (2000). Customer loyalty in the hotel industry: the role of customer satisfaction and image. International Journal of Contemporary Hospitality Management, 12(6), 346-351. https://doi.org/https://doi.org/10.1108/09596110010342559

Karyose, H., Astuti, W., \& Ferdiansjah, A. (2017). Customer Loyalty: The Effect of Service Quality, Corporate Image, Customer Relationship Marketing and Customer Satisfaction as Intervening Variable-An Empirical Analysis of Bank Customers in Malang City. Marketing and Branding Research, 4(2017), 336-347.

Kheng, L. L., Mohamad, O., Ramayah, T., \& Mosahab, R. (2010). The Impact of Service Quality on Customer Loyalty: A Study of Banks in Penang, Malaysia. International Journal of Marketing Studies, 2(2), 57-66. https://doi.org/DOl:10.5539/ijms.v2n2p57

Kim, H.-B., \& Kim, W. G. (2005). The Relationship Between Brand Equty and Firms Performance in Luxury Hotels and Chain Restaurant. Woo GonKim, 26(4), 549-560. https://doi.org/https://doi.org/10.1016/j.tourman.2004.03.010

Kim, H. D., \& Lough, N. (2007). An Investigation Into Relationships Among Constructs of Service Quality, Customer Satisfaction, And Repurchase Intention in Korean Private Golf Courses. Journal of Research, 2(1), 14-22.

Kotler, P., \& Keller, K. L. (2016). Marketing Management (15th ed.). New Jersey: Pearson Education.

Laksana, F. (2008). Manajemen Pemasaran. Jakarta: Graha IImu. 
Ledden, L., Kalafatis, S. P., \& Mathioudakis, A. (2011). The idiosyncratic behaviour of service quality, value, satisfaction, and intention to recommend in higher education: An empirical examination. Journal of Marketing Management, 27(11-12), 1232-1260. https://doi.org/https://doi.org/10.1080/0267257X.2011.611117

Liat, C. B., Mansori, S., Chuan, G. C., \& Imrie, B. C. (2017). Hotel Service Recovery and Service Quality: Influences of Corporate Image and Generational Differences in the Relationship between Customer Satisfaction and Loyalty. Journal of Global Marketing, $0(0), 1-10$. https://doi.org/DOI: 10.1080/08911762.2016.1262932

Lovelock, C. H., \& Wright, L. K. (2007). Manajemen Pemasaran Jasa. Jakarta: PT Indeks.

Lunarindiah, G. (2016). The Influence of Corporate Image, Service Quality, Perceived Value Toward Student Satisfaction and Student Loyalty. Jurnal Manajemen Dan Pemasaran Jasa, 9(2), 239-252.

Lupiyoadi, R., \& Hamdani, A. (2006). Manajemen Pemasaran Jasa. (2, Ed.). Jakarta: Salemba Empat.

Majid, M. A. A., Samsudin, A., Noorkhizan, M. H. I., Zaki, M. I. M., \& Bakar, A. M. F. A. (2018). Service Quality, Food Quality, Image and Customer loyalty: An Empirical Study at a Hotel Restaurant. International Journal of Academic Research in Business and Social Sciences, 8(10), 1432-1446. https://doi.org/DOI: 10.6007/IJARBSS/v8-i10/5310

Markovic, S., Jankovic, S. R., \& Segaric, K. (2010). Does Restaurant Performance Meet Customers' Expectations? An Assessment of Restaurant Service Quality Using a Modified Dineserv Approach. Tourism \& Hospitality Management, 16(2), 181-195.

Mazanec, J. A. (1995). Positioning analysis with self - organising maps: An exploratory study on luxury hotels. The Cornell H. R. A. Quarterly, 36(6), 80-95. https://doi.org/https://doi.org/10.1016/0010-8804(96)81007-X

Mohajerani, P., \& Miremadi, A. (2012). Customer Satisfaction Modeling In Hotel Industry: A Case Study of Kish Island In Iran. International Journal of Marketing Studies, 4(3), 134-152.

Mohamad, H. A. D., Yazid, M. S. A., Khatib, A., \& Azam, S. M. F. (2017). Service Quality, Customer Satisfaction And Customer Loyalty of the Hotel Industry in United Arab Emirates (UAE): a Measurement Model. European Journal of Management and Marketing Studies, 2(4), 1-26. https://doi.org/doi: 10.5281/zenodo.1066572

Mutmainnah. (2017). Pengaruh Kualitas Layanan dan Citra Perusahaan Terhadap Kepuasan dan Loyalitas Nasabah. Jurnal Manajemen Dan Pemasaran Jasa, 10(2), 201-216. https://doi.org/Doi: http://dx.doi.org/10.25105/jmpj.v10i1.2344

Nasution, M. I., Fahmi, M., Jufrizen, J., Muslih, M., \& Prayogi, M. A. (2020). The Quality of Small and Medium Enterprises Performance Using the Structural Equation Model-Part Least Square (SEM-PLS). Journal of Physics: Conference Series, 1477(2020), 1-7.

Nurcahyo, R., Fitriyani, A., \& Hudda, I. N. (2017). The Influence of Facility and Service Quality towards Customer Satisfaction and Its Impact on Customer Loyalty in Borobudur Hotel in Jakarta. Binus Business Review, 8(1), 23-29. https://doi.org/DOl: 10.21512/bbr.v8i1.1790

Oliver, R. L. (2010). Satisfaction: A Behavioral Perpective on The Customer. New York: McGraw-Hill.

Ostrowsky, P. L., O'Brien, T. V, \& O'Brien, T. V. (1993). Service quality and customer satisfaction in the commercial airline industry. Journal of Travel Research, 33(2), 16-24.

Pinzón, S. O., \& Saura, I. G. (2011). National index of consumer satisfaction. A proposal for a review of literature. Cuadernos de Administración, 24(43), 35-57.

Purbandari, E., Sugandini, D., \& Sutiono, H. T. (2018). Word Of Mouth Sebagai Konsekuensi Kepuasan Pelanggan. Jurnal Manajemen Dan Pemasaran Jasa, 11(1), 111-124. https://doi.org/Doi: http://dx.doi.org/10.25105/jmpj.v10i1.2355

Radiman, R., Gunawan, A., Wahyuni, S. F., \& Jufrizen, J. (2018). The Effect of Marketing Mix, Service Quality, Islamic Values and Institutional Image on Students' Satisfaction and Loyalty. Expert Journal of Marketing, 6(2), 95-105.

Rahma, L. (2015). Antesen Customer Loyalty Pada Budget Hotel. Jurnal Manajemen Dan Pemasaran Jasa, 8(2), $55-70$.

Ranjbarian, B., Sanayei, A., Kaboli, M. R., \& Hadadian, A. (2012). An Analysis of Brand Image, Perceived Quality, Customer Satisfaction And Re-purchase Intention In Iranian Department Stores. International Journal of Business and Management, 7(6), 40-48.

Ratnasari, R. T., \& Aksa, M. (2011). Manajemen Pemasaran Jasa. Bogor: Ghalia Indonesia.

Saleem, H., \& Raja, N. S. (2014). The Impact of Service Quality on Customer Satisfaction, Customer Loyalty and Brand Image: Evidence from Hotel Industry of Pakistan. IOSR Journal of Business and Management 
(IOSR-JBM), 16(1), 117-122.

Santoso, S. (2012). Analisis SEM Menggunakan AMOS. Jakarta: PT Elek Media Komputindo.

Selnes, F. (1993). An Examination of the Effect of Product Performance on Brand Reputation, Satisfaction and Loyalty. European Journal of Marketin, 27(9), 19-35. https://doi.org/https://doi.org/10.1108/03090569310043179

Sumarwan, U. (2012). Riset Pemasaran dan Konsumen. Bogor: IPB Press.

Supranto, J. (2011). Pengukuran Tingkat Kepuasan Pelanggan Untuk Menaikkan Pangsa Pasar (4th ed.). Jakarta: PT Rineka Cipta.

Susanti, C. E. (2019). The Effect of Service Quality and Perceived Price Fairness on Consumer Loyalty through Consumer Satisfaction on Budget Hotel in East Java. Indian Journal of Science and Technology, 12(6), 17. https://doi.org/DOI: 10.17485/ijst/2019/v12i6/141954

Susanti, E. (2018). Kualitas Layanan Internal yang Memengaruhi Kepuasan Nasabah dengan Menggunakan Kualitas Layanan Eksternal sebagai Variabel Mediasi. Jurnal Manajemen Dan Pemasaran Jasa, 11(1), 95110. https://doi.org/Doi: http://dx.doi.org/10.25105/jmpj.v10i1.2099

Sutisna. (2001). Perilaku Pelanggan Dan Komunikasi Pemasaran (Pertama). Bandung: PT Remadja Rosdakarya.

Tefera, O., \& Govender, K. (2015). Hotel Grading, Service Quality, Satisfaction and Loyalty - Proposing a Theoretical Model and Relationship. African Journal of Hospitality, Tourism and Leisure, 4(Special Edition), $1-17$.

Tjiptono, F. (2012). Service Management Mewujdukan Pelayanan Prima. Yogyakarta: PT Andi Offset.

Torres-Moraga, E., Vásquez-Parraga, A. Z., \& Zamora-González, J. (2008). Customer Satisfaction And Loyalty: Start With The Product, Culminate With The Brand. Journal of Consumer Marketing, 25(5), 302-313. https://doi.org/https://doi.org/10.1108/07363760810890534

Venkateswarlu, P., Ranga, V., \& Sreedhar, A. (2015). Antecedents of customer loyalty in hospitals. The IUP Journal of Marketing Management, 14(4), 7-19.

Widyawati, N. (2008). Pengaruh Kepercayaan Dan Komitmen Serta Bauran Pemasaran Jasa Terhadap Loyalitas Pelanggan Di Hotel Zakiah Medan. EKUITAS : Jurnal Ekonomi Dan Keuangan, 12(1), 74-96.

Woodside, A. W., Frey, L. L., \& Daly, R. T. (1997). Linking service quality, customer satisfaction, and behavioural intention. Journal of Health Care Marketing, 9(4), 5-17.

Yamit, Z. (2013). Manajemen Kualitas Produk \& Jasa. Yogyakarta: Ekonisia.

Yoon, E., Guffey, H. J., \& Kijewski, V. (1993). No Title. Journal of Bussiness Reseach, 27(3), 215-228. https://doi.org/https://doi.org/10.1016/0148-2963(93)90027-M

Zakiy, M. (2019). Citra Perusahaan Sebagai Variabel Pemoderasi Pengaruh Layanan Terhadap Kepuasan Pasien dan Niat Beralih. Jurnal Manajemen Dan Pemasaran Jasa, 12(1), 51-64. https://doi.org/Doi: http://dx.doi.org/10.25105/jmpj.v12i1.3149

Zhao, X., Lynch, J. G., \& Chen, Q. (2010). Reconsidering Baron and Kenny: Myths and Truths about Mediation Analysis. Journal of Consumer Reasearch, Inc, 37(August), 197-206. https://doi.org/DOI: 10.1086/651257 